\title{
GENOMIC RELATEDNESS OF TURKEY CORONAVIRUSES, BOVINE CORONAVIRUS AND INFECTIOUS BRONCHITIS VIRUS OF CHICKENS.
}

\author{
M. M. Ismail* and A. Y. Metwally** \\ *Dept. of Poultry and Fish, Faculty of Veterinary Medicine, Kafr-El-Sheikh University \\ **Animal Health Research Institute, Kafr El-Sheikh Prov. Laboratory
}

\begin{abstract}
The discrepant findings of antigenic relationship of turkey coronavirus (TCV) to infectious bronchitis virus (IBV) and bovine coronavirus (BCV) lead us to study the genomic relatedness of TCVs to $I B V$ and $B C V$. A one step reverse transcription (RT)-polymerase chain reaction (PCR) targeting a 525-base pair fragment of the spike 2 (S2) gene of BCV was used in a trial to detect TCVs isolated from diarrheic turkeys and a prototype TCV obtained from the American Type Culture Collection. The one-step RT-PCR amplified cell culturepassaged isolates of calf diarrhea strains of $B C V$, but none of the tested TCVs. On the other hand when we used primers designed from $S 2$ gene of IBV, The same TCVs could be detected using the S2 IBV primers of IBV of chickens which amplified a 820-base pair region spanning portions of the $S 2$ glycoprotein genes of IBV and TCV. These findings provide evidence that TCV is more closely related to IBV.
\end{abstract}

\section{INTRODUCTION}

The Coronaviridae is a family of single stranded, enveloped, plussense RNA viruses that infects many mammalian and avian species causing variety of serious diseases. Until 1992, the Coronaviridae was a monogeneric family including only coronaviruses as a sole genus of the family then the International Committee of Taxonomy of Viruses decided to include the toroviruses in the Coronaviridae family based on 
their morphology, replication strategy, and genome organization which are similar to coronaviruses. Turkey coronavirus (TCV) is a member of cornaviruses, which causes an economically important disease in turkeys called bluecomb or transmissible enteritis. The disease was first recorded in turkey flocks in USA in 1950's but it was not until 1973 when the causative agent was classified as coronavirus (Panigraphy et al., 1973). TCV is also associated with Poult enteritis-mortality syndrome (PEMS), a transmissible multifactorial disease typically affecting turkeys between 7 and28days of age.The disease is characterized by diarrhea, dehydration, weight loss, anorexia, immune dysfunction, marked growth depression, and increased mortality in turkeys (Barnes et al., 1997). Inability to adapt the virus to grow on tissue cultures is always an obstacle towards studies on TCV.

Enteric diseases are of major economic importance in poultry. Numerous viruses have been identified as important causes of gastrointestinal tract diseases of chickens and turkeys. The result of infection by any of these viruses ranges from inapparent subclinical infection to severe devastating disease conditions. The resulting form of the disease induced by these infections is influenced by many contributing factors such as age, immune status of birds, strain of virus involved, management, nutrition, and other complicating infections. Not only do these enteric diseases result in mortality,decreased feed utilization and uneven growth rate but also predispose the gastrointestinal tract to other opportunistic enteric pathogens. Mucosal damage provoked by enteric viruses provides a portal of entry for other intestinal pathogens and interfere with absorption of essential nutrients leading to growth retardation and nutritional deficiencies. A variety of infectious agents can affect the GI tract but virus infections constitute the major cause, which have serious impact on flock health and performance. 
Virus infections of the gastrointestinal tract are common in turkeys. The economic losses from enteric diseases in commercial poultry are greater than losses due to diseases affecting other systems. Considerable part of these losses is due to mortality but the major part comes from depressed growth rate, increased feed conversion ratio, increased vulnerability to other diseases, and medication costs. Enteric infections occur in all age groups with more tendency to affect the younger ages (Guy 1998). Rotaviruses including group A and group D (Bergeland et al., 1977; McNulty and Guy 1997; McNulty 1997; Theil and Saif 1987 and Yu et al., 2000), coronaviruses (Dea and Tijssen 1988; Nagaraja and Pomeroy 1997 and Panigraphy et al., 1973), enterovirus (Guy and Barnes 1991; Hayhow and Saif 1993; Hayhow et al., 1993; McNulty et al., 1987; Saif et al., 1985 and Saif et al., 1990), adenovirus (Fadly et al., 1985) astrovirus (Reynolds 1997; Reynolds et al., 1987 and Reynolds and Saif 1986), reovirus (Goodwin et al., 1984), parvovirus (Saif et al., 1985) and stunting syndrome agent (Ali and Reynolds, 2000) have been identified as causes of enteric diseases in turkeys. It is usually difficult to assess the individual roles of each of these enteric viruses, because enteric diseases usually have multiple etiology and some of these viruses can be found in healthy turkeys. There are conflicting reports about antigenic relatedness of TCV to both bovine coronavirus (BCV) and infectious bronchitis virus (IBV) of chickens. (Dea et al., 1990 and Guy, 2000) therefore this study was pursued to further outline the genomic relatedness of TCV to both group 2 of coronaviruses which includes also BCV and group 3 of coronaviruses which include IBV using RT-PCR.

\section{MATERIALS AND METHODS}

\section{Viruses}

The TCVs used in this study were the American Type Culture Collection turkey coronavirus (ATCC VR-911) supplied as intestines from diarrheic turkeys and 5 isolates that were isolated from diarrheic 
turkey flocks. All samples were confirmed positive for coronaviruses by immune electron microscopy (IEM) and by fluorescent antibody technique (FA) using turkey hyperimmune serum. The Arkansas and Massachusetts IBVs were propagated in chicken embryos. BCV strains included the calf diarrhea (CD) Mebus strain (Cho et al., 2001).

\section{Propagation of viruses}

Turkey and chicken embryos used for propagation of different coronaviruses originated from specific-pathogen-free (SPF) flocks .Both ATCC TCV and TCVs were propagated in turkey embryos. The fecal samples containing TCVs and negative control samples were clarified at $3000 \mathrm{Xg}$ for 30 minutes and the supernatants were filtered through 0.8 $\mu \mathrm{m}$ filters and then through $0.45 \mu \mathrm{m}$ filters (Corning Glassware, New York). A volume of $0.2 \mathrm{ml}$ of filtrate was inoculated into 22-day-old turkey embryos via the amniotic cavity route. The intestinal tracts of inoculated embryos were harvested at 48 hours postinoculation. Arkansas and Massachusetts strains of IBV were inoculated into the allantoic cavity of 10-day-old SPF chicken embryos and the viruscontaining allantoic fluids were collected 24-30 hours post-inoculation. Negative control embryos were inoculated with phosphate buffered saline (PBS; $\mathrm{pH}$ 7.4). The Mebus strain of BCV was passaged as previously described (Cho et al., 2001) in human rectal adenocarcinoma (HRT-18) cells.

\section{Intestinal homogenates processing for virus purification}

The inoculated turkey embryo intestinal homogenates were diluted 1:10 in PBS and then clarified by centrifugation $(1,000 \mathrm{X} \mathrm{g}$ for 30 minutes at $4 \mathrm{C}$ ). For virus purification, supernatants were purified on 20 to $50 \%$ sucrose density gradient by ultracentrifugation $(112,000 \mathrm{X}$ g for 2 hours at $4 \mathrm{C}$ ). The band at the $20 / 50 \%$ interface was collected, pelleted by ultracentrifugation (112,000 X $\mathrm{g}$ for 2 hours at $4 \mathrm{C})$, resuspended in Eagle's minimum essential medium (EMEM) and stored at - $70 \mathrm{C}$. 


\section{Extraction of viral RNA for BCV RT-PCR}

The Mebus strain of CD BCV (Cho et al., 2001) was diluted in EMEM. For TCV RNA extraction, TCV infected turkey embryo intestinal homogenates and sucrose gradient purified TCV were used. Mock infected turkey embryos were also used. RNA was extracted based on the acid guanidinium-phenol-chloroform RNA extraction method (4). Briefly, $500 \mu 1$ Solution D (4M guanidinium thiocyanate, 25mM Sodium

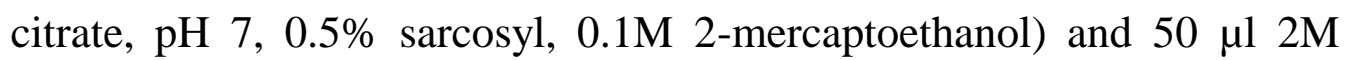
sodium acetate ( $\mathrm{pH} 4.0$ ) were added into tubes containing $200 \mu \mathrm{l}$ of BCV specimens, ATCC TCV, fecal suspensions (1:25 dilutions), purified TCV and TCV inoculated embryos intestinal homogenate supernatants (1:10 dilutions). After mixing, $500 \mu \mathrm{l}$ water saturated phenol ( $\mathrm{pH} 4.5)$ and 100 $\mu 1$ chloroform and isoamylalcohol (49:1) were added, vortexed briefly and placed on ice for $15 \mathrm{~min}$. The mixtures were centrifuged at 20,800 X $\mathrm{g}$ for $20 \mathrm{~min}$ at $4 \mathrm{C}$ and the supernatants were transferred into a new tube. To remove non-specific inhibitors from the extracted samples, the supernatants were purified using the Rnaid kit according to the manufacturer's instructions (BIO 101, Inc. La Jolla, California). As negative controls, RNA was extracted from mock-infected HRT-18 cells, and the mock-infected turkey embryos.

\section{Extraction of viral RNA for IBV RT-PCR}

The IBV laden allantoic fluid and TCVs inoculated embryo intestinal homogenate supernatants (1:10 dilutions) were concentrated by ultracentrifugation at $100,000 \mathrm{X} \mathrm{g}$ for 3 hours and then used for RNA extraction by the guanidium isothiocyanate-phenol chloroform method using a commercial kit (Trizol LS reagent, Life Technologies, Grand Island, NY) according to the manufacturer instructions. Briefly, $0.25 \mathrm{ml}$ of purified IBV was mixed with $0.75 \mathrm{ml}$ of Trizol LS reagent. After 5 minutes at room temperature, $0.2 \mathrm{ml}$ of chloroform was added for phase separation. The mixture was centrifuged at $12,000 \mathrm{Xg}$ for 15 minutes at 4 $\mathrm{C}$ and the aqueous phase was collected. Isopropyl alcohol was added to 
the aqueous phase to precipitate the RNA. After centrifugation at 12,000 $\mathrm{X} \mathrm{g}$ for 10 minutes the pelleted RNA was washed with $75 \%$ ethanol, dried for 10 minutes at room temperature, and dissolved in $20 \mu \mathrm{l}$ of diethyl pyrocarbonate (DEPC)-treated water. Allantoic fluids and intestinal homogenates from mock-infected SPF embryos were used as negative control.

\section{Preparation of oligonucleotide primers}

\section{BCV primers}

Primers were designed from the spike 2 (S2) subunit of the BCV S protein gene. primers were selected for the conserved region of the $S$ protein gene of $3 \mathrm{BCV}$ strains [Accession No. M64667 (BCV-19 strain), D00731 (BCV F-15 strain), and M64667 (BCV-LY138 strain)], upstream primer; 5'-ATTGTACTGGAGGTGCCGAA-3' -downstream primer; 5'-ACTAGTGTAGAATCACTAAG-3' - predicted PCR product: 525 base pairs

\section{IBV Primers}

Primers were designed from the S2 subunit of the IBV S protein gene. Primers were selected for the conserved region of the $S$ protein gene of 3 IBV strains [Accession No. X02342 (Beaudette strain), XI 5832 (D274 strain), and U05739 (CU-T2 strain)].,- upstream primer; 5'GTTTGCTTGTGTTGCC-3' - downstream primer; 5'-TTACACTTACATAATTTGCT-3' - predicted PCR product: 820 base pairs

\section{RT-PCR procedure using BCV primers}

A one step RT-PCR assay was performed with modifications as described previously (Cho et al., 2001). The tube containing $5 \mu 1$ of the RNA samples (BCV, TCV) and $1 \mu$ of DMSO was incubated at $70 \mathrm{C}$ for $10 \mathrm{~min}$ and then quenched on ice. Subsequently, $44 \mu \mathrm{l}$ of the RT-PCR mixture was added. The RT-PCR mixture consisted of $5 \mu 1$ of $10 \mathrm{X}$ buffer [100 mM Tris- $\mathrm{HCl}(\mathrm{pH} 8.3), 500 \mathrm{mM} \mathrm{KCl}, 15 \mathrm{mM} \mathrm{MgCl} 2,0.01 \%$ gelatin], $5 \mu \mathrm{l}$ of $\mathrm{MgCl} 2(25 \mathrm{mM}), 1 \mu \mathrm{l}$ of $10 \mathrm{mM}$ dNTPs, $1 \mu \mathrm{l}$ of the 
upstream primer $(50 \mathrm{pmol}), 1 \mu \mathrm{l}$ of the downstream primer $(50 \mathrm{pmol})$, $0.5 \mu \mathrm{l}$ of RNAsin (Promega Corporation), and $0.5 \mu \mathrm{l}$ of AMV RT (Promega Corporation), $0.5 \mu \mathrm{l}$ of Taq polymerase (Promega Corporation) $(5 \mathrm{U} / \mu \mathrm{l})$. The mixture was incubated for $60 \mathrm{~min}$ at $42 \mathrm{C}$, preheated for $5 \mathrm{~min}$ at $94 \mathrm{C}$, subjected to 35 cycles of $1 \mathrm{~min}$ at $94 \mathrm{C}, 1$ min at $58 \mathrm{C}, 2 \mathrm{~min}$ at $72 \mathrm{C}$ and final $7 \mathrm{~min}$ incubation at $72 \mathrm{C}$. The PCR products were visualized on $1.5 \%$ agarose gels stained with ethidium bromide.

\section{RT-PCR using IBV primers}

To perform the RT-PCR assay with RNA extracted from the IBV, TCVs and negative control samples, the RT-PCR procedure was done as described previously (Andreasen et al., 1991) but with modifications. In addition a reverse transcription step was added as follows; The tube containing $5 \mu \mathrm{l}$ of RNA sample and $2 \mu \mathrm{l}$ of downstream IBV primer (25 pmol) and $4 \mu$ l of DEPC treated water was incubated in a boiling water bath for 2 minutes then quenched on ice for 5 minutes. Subsequently $9 \mu 1$ of the RT-PCR mixture was added. The RT-PCR mixture consisted of 4 $\mu 1$ of $5 x$ RT buffer, $2 \mu 1$ of 0.1 dithiothereitol, $2 \mu 1$ of $10 \mathrm{mM}$ dNTPs (Promega Corporation), $0.5 \mu \mathrm{l}$ RNAsin (Promega Corporation) and 0.5 $\mu 1 \mathrm{AMV}$ RT (Promega Corporation). The mixture was incubated at $42 \mathrm{C}$ for 90 minutes. After incubation $10 \mu \mathrm{l}$ of the resulting template was mixed with $50 \mu 1$ of PCR mixture. The PCR mixture consisted of $5 \mu 1$ of 10x buffer [100 mM Tris- $\mathrm{HCl}(\mathrm{pH} 8.3), 500 \mathrm{mM} \mathrm{KCl,} 15 \mathrm{mM} \mathrm{MgCl}$, $0.01 \%$ gelatin], $5 \mu \mathrm{l}$ of $\mathrm{Mg} \mathrm{Cl}_{2}(25 \mathrm{mM})$ (Promega Corporation), $1 \mu \mathrm{l}$ $10 \mathrm{mM}$ dNTP (Promega Corporation), $1 \mu \mathrm{l}$ of upstream primer (25 pmol), $1 \mu \mathrm{l}$ of downstream primer $(25 \mathrm{pmol}), 0.5 \mu \mathrm{l}$ of Taq polymerase (Promega Corporation) and $26.5 \mu \mathrm{l}$ DEPC treated water. The mixture was preheated at $94 \mathrm{C}$ for 5 minutes then subjected to 35 cycles of one minute at $94 \mathrm{C}, 2$ minutes at $37 \mathrm{C}, 5$ minutes at $72 \mathrm{C}$ and a final 15 minutes incubation at $72 \mathrm{C}$. The PCR products were visualized on $1.5 \%$ agarose gels stained with ethidium bromide. 


\section{RESULTS}

A specific 525 bp band was detected after RT-PCR with Mebus strain of BCV. To study the reactivity of the primers, RT-PCR was also performed with RNA extracted from transmissible gastroenteritis coronavirus and mock-infected HRT-18 cells. Using The BCV primers, the RT-PCR produced no bands with the above RNA samples. When RT-PCR was performed on the extracted TCV RNA from ATCC strain, 5 TCV from diarrheic turkey flocks, and from same viruses after purification using BCV primers, there were no detectable bands. (Fig. 1).

On the other hand, when primers from IBV were used, bands of predicted size $(820 \mathrm{bp})$ were detected when RT-PCR was performed on RNA extracted from both Arkansas and Massachusetts strains of IBV. The same size bands were detected when performing the RT-PCR on RNA extracted from all concentrated isolates of TCV including the ATCC strain (Fig. 2-) .

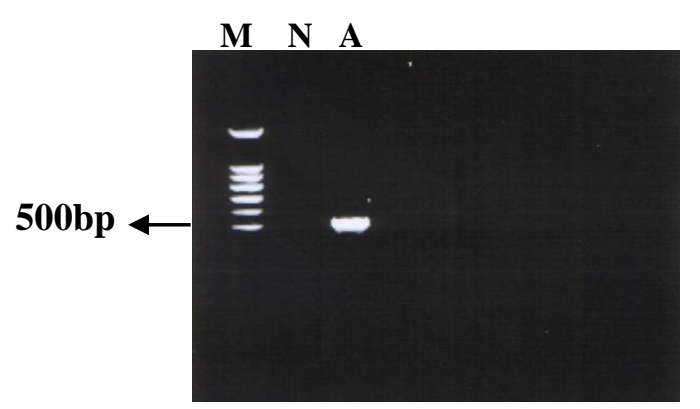

Fig. (1): specificity of primers to $B C V . M=$ Marker, $N=$ Negative control. $\mathrm{A}=$ Positive control (BCV mebus strain).

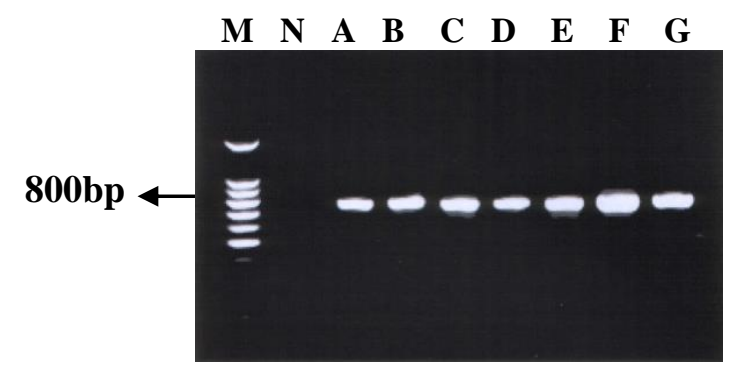

$\overline{\text { Kafrelsheikh Vet. Med. J. Vol. } 4 \text { No. } 2 \text { (2006) }}$ 
Fig. (2): Results of IBV PCR with TCVs. M= Marker, N= Negative control $\mathrm{A}, \mathrm{B}=$ Massachusetts and Arkanses IBV. C-G $=$ TCVs.

\section{DISCUSSION}

In the present study $\mathrm{TCV}$ s isolated from diarrheic turkeys and the ATCC TCV were tested for their genomic relationships to both BCV and IBV. Attempts were unsuccessful to amplify a part of TCVs genome using primers from BCV in a RT-PCR which could amplify BCV S2 gene. Meanwhile, When we used primers prepared from S2 gene of IBV, to amplify the $\mathrm{S} 2$ gene of TCVs, a predicted size band was detected with IBV and TCVs.

In earlier studies of TCVs in 1973 (Ritchie et al., 1973) using IEM and $\mathrm{HI}$ test, the virus was shown to be unrelated to either group $2 \mathrm{BCV}$ or group $3 \mathrm{IBV}$. Hence TCV was assigned to antigenic group 4 of coronaviruses. Other researchers found that TCV was antigenically related to BCV (Dea et al., 1990; Dea et al., 1991 and Verbeek and Tijssen 1991) and proposed that TCV must be included with group 2 coronaviruses. Our findings are consistent with the more recent findings of Guy et al., (1997); Breslin et al., (1999); Ismail et al., (2001) and Lin et al., (2004) who reported that recent TCVs isolated from PEMS cases were closely related to IBV based on immunofluorescence, immunoperoxidase procedures and on nucleocapsid gene sequencing. Cavanagh et al., (2001) also found that a TCV isolated from turkeys in Europe is genetically related to IBV of chickens.

The spike glycoprotein of coronaviruses induces neutralizing antibodies and attaches to host cells (Collins et al., 1982). The sequence of the S1 gene fragment shows major sequence variation, whereas the S2 portion contains conserved sequences. Moreover, changes in the $\mathrm{S}$ protein may lead to altered antigenicity and virulence (Laude et al., 1993). 
In conclusion, based on our current results, TCVs and IBV share antigenic and genomic properties and it is proposed to consider including them as group 3 avian coronaviruses.

\section{REFERENCES}

- Ali, A. and Reynolds, D. L. (2000): Characterization of the stunting syndrome agent: physicochemical properties. Avian Dis. 44: 426-433.

- Andreasen, J. R.; Jackwood, M. W. and Hilt, D. A. (1991): Polymerase chain reaction amplification of the genome of infectious bronchitis virus. Avian Dis. 35: 216-220.

- Barnes, H. J. and Guy, J. S. (1997): Poult Enteritis-Mortality Syndrome ("spiking mortality") of turkeys. In: Diseases of poultry, 10th ed. B. W. Calnek, H. J. Barnes, C. W. Beard, L. R. McDougald, and Y. M. Saif, eds. Iowa State University Press, Ames, Iowa. pp. 1025-1031. 1997.

- Bergeland, M. E.; McAdaragh, J. P. and Stotz, I. (1977): Rotaviral enteritis in turkey poults. Proceedings of the 26th Western Poultry Disease Conference. pp.129-130.

- Breslin, J. J.; Smith, L. G.; Fuller, F. G. and Guy, J. S. (1999): Sequence analysis of the matrix/nucleocapsid gene region of turkey coronavirus. Intervirology. 42: 22-29.

- Cavanagh, D.; Mawditt,K.; Sharma, M.; Drury, S. E.; Ainsworth, H. L.; Britton, P. and Gough, R. E. (2001): Detection of a coronavirus from turkey poults in Europe genetically related to infectious bronchitis virus of chickens. Avian Pathol. 30: 355-368.

- Cho, K.-O.; Hasoksuz, M.; Nielson, P. R.; -Chang, K. O.; Lathrop, S. and Saif, L. J. (2001): Cross-protection studies between respiratory and calf diarrhea or winter dysentery 
coronavirus strains in calves and RT-PCR and nested PCR for their detection. Arch. Virol.

- Collins, A.; Knobler, R, Powell, H. \& Buchmeier, M. (1982): Monoclonal antibodies to murine hepatitis virus-4 (strain JHM) define the viral glycoprotein responsible for attachment and cell-cell fusion. Virology, 119: 358-371.

- Dea, S. and Tijssen, P. (1988): Viral agents associated with outbreaks of diarrhea in turkey flocks in Quebec, Canadian J. Vet. Res.

52: 53-57.

- Dea, S.; A. J. Verbeek, A. J.; and Tijssen, P. (1991): Transmissible enteritis of turkeys: experimental inoculation studies with tissue-culture-adapted turkey and bovine coronaviruses. Avian Dis. 35: 767-777.

- Dea, S.; Verbeek, A. J.; and Tijssen, P. (1990): Antigenic and genomic relationships among turkey and bovine coronaviruses. J. Virol. 64: 3112-3118.

- Fadly, A. M.; Nazerian, K.; Nagaraja, K. and Below, G. (1985): Field vaccination against hemorrhagic enteritis of turkey. Avian Dis. 29: 768-777. 1

- Goodwin, M. A.; Latimer, K. S.; Nersessian, B. N. and Fletcher, O. J. (1984): Quantitation of intestinal D-xylose absorption in normal and reovirus-inoculated turkeys. Avian Dis. 28: 959-967.

- Guy, J. S. (1998): New methods for diagnosis of turkey coronavirus infections. Proceedings of the $49^{\text {th }}$ North Central Avian Disease Conference. Pp. 8-10. 
- Guy, J. S., and Barnes, H. J. (1991): Partial characterization of a turkey enterovirus-like virus. Avian Dis. 85: 197-203.

- Guy, J.; Barnes, H. J.; Smith, L. J. and J. Breslin, J. (1997). Antigenic characterization of a Turkey coronavirus identified in poult enteritis and mortality syndrome-affected turkeys. Avian Dis. 41: 583-590.

- Guy, S. J. (2000): Turkey coronavirus is more closely related to avian infectious bronchitis virus than to mammalian coronaviruses: a review. Avian Pathol. 29: 207-212.

- Hayhow, C. S., and Saif. Y. M. (1993): Experimental infection of specific-pathogen-free turkey poults with single and combined enterovirus and group A rotavirus. Avian Dis. 37: 546-557.

- Hayhow, C. S.; Saif, Y. M.; Kerr, K. M. and Whitmoyer, R. E. (1993): Further observations on the enterovirus infection in specific-pathogen-free turkey poults. Avian Dis. 37: 124-134.

- Ismail, M. M.; Cho, K.-O.; Hasoksuz, M.; Saif, L. J. and Saif, Y. M. (2001): Antigenic and genomic relatedness of turkey origin coronaviruses, bovine coronaviruses and infectious bronchitis virus of chickens. Avian Dis. 45: 978-984.

- Laude,H.; Van Reeth,K.and Pensaert,M. (1993): Porcine respiratory coronavirus: molecular features and virus-host interactions. Vet. Res., 24: 125-150.

- Lin, T. L.; Loa, C. C. and Wu, C. C. (2004): Complete sequences of 3 ' end coding region for structural protein genes of turkey coronavirus. Virus Research. 106: 61-70.

- McNulty M. S. (1997). Rotavirus Infections. In: Diseases of poultry, $10^{\text {th }}$ ed. B. W. Calnek, H. I. Barnes, C. W. Beard, L. R. 
McDougald, and Y. M. Saif, eds. Iowa State University Press, Ames, Iowa. Pp. 692- 701.

- McNulty M. S.; and Guy, J. S. (1997). Rotavirus infections. In: Diseases of poultry, 10th ed. B. W. Calnek, H. J. Barnes, C. W. Beard, L. R. McDougald, and Y. M. Saif, eds. Iowa State University Press, Ames, Iowa Pp. 706-710.

- McNulty,M.S.;Allan, G. M.; J. B. McFerran, J. B. (1987): Isolation of a novel avian entero-like virus. Avian Pathol. 16: 331-337.

- Nagaraja, K. V. and Pomeroy, B. S. (1997): Coronaviral enteritis of turkeys (bluecomb disese) In: Diseases of poultry, 10th ed. B. W. Calnek, H. J. Barnes, C. W. Beard, L. R. McDougald, and Y. M. Saif, eds. Iowa State University Press, Ames, Iowa. pp. 686-692.

- Panigraphy, B.; Naqi, S. A. and Hall, C. F. (1973): Isolation and characterization of viruses associated with transmissible enteritis (bluecomb) of turkey. Avian Dis. 17: 430-438.

- Reynolds, D. L. (1997): Astrovirus infections. In: Diseases of poultry, 10 th ed. B. W. Calnek, H. J. Barnes, C. W. Beard, L. R. McDougald, and Y. M. Saif, eds. Iowa State University Press, Ames, Iowa. pp. 701-705.

- Reynolds, D. L. and Saif, Y. M. (1986): Astrovirus: a cause of an enteric disease in turkey poults. Avian Dis.30: 728-735.

- Reynolds, D. L.; Saif, Y. M. and K. W. Theil, K. W. (1987): Enteric viral infections of turkey poults: incidence of infection. Avian Dis. 31: 272-276.

- Ritchie, A. E.; Deshmukh, D. R.; Larsen, C. T.; and Pomeroy, P. S. (1973): Electron microscopy of coronavirus-like particles characteristic of turkey bluecomb disease. Avian Dis. 17: 546558. 
- Saif, L. J.; Saif, Y. M. and Theil, K. W. (1985): Enteric viruses in diarrheic turkey poults. Avian Dis. 29: 798-811.

- Saif, Y. M.; Saif, L. J.; Hofacre, C. I.; Hayhow, C.; Swayne, D. E. and Dearth, R. N. (1990): A small round virus associated with enteritis in turkey poults. Avian Dis. 34: 762-764.

- Theil, K. W., and Saif, Y. M. (1987): Age related infections with rotavirus, rotavirus like virus and atypical rotavirus in turkey flocks. J. Clin. Microbiol. 25: 333-337.

- Verbeek, A. and Tijssen, P. (1991): Sequence analysis of the turkey enteric coronavirus nucleocapsid and membrane protein genes: a close genomic relationship with bovine coronavirus. J. Gen. Virol. 72: 1659-1666.

- Yu, M.; Ismail, M. M.; Qureshi, M. A.; Dearth, R. N.; Barnes, H. J. and Saif, Y. M. (2000): Viral agents associated with poult enteritis and mortality syndrome: The role of a small round virus and a turkey coronavirus. Avian Dis. 44: 297-304.

$$
\begin{aligned}
& \text { العلاقة الجينية للفيروس التاجى فى الرومى بكل من الفيروس التاجى للأبقار } \\
& \text { وفيروس مرض الإلتهاب الثعبى المعدى فى الاجياج } \\
& \text { "محمود موسى إسعاعيل " "عبل النبى يونس متولحى } \\
& \text { "قسم الدواجن والأسماك كلية الطب البيطرى - جامعة كفر الشيخ } \\
& \text { " معهد بحوث صحة الحيوان - المعمل الفرعى بكفر الثيخ }
\end{aligned}
$$

إن النتائج المتعارضــة التىى أنشارت اليها الأبحـاث السـابقة عن العلاقـة الجينيـة والأنتيجينيـة للفيروس التاجى فى الرومى المسبب لمرض العرف الأزرق فى الرومى والذى يتميز بالإلتهابات المعوية

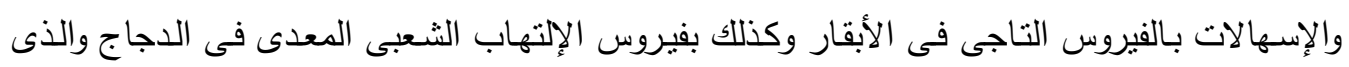


يسبيه أيضا أحد هذه الفيروسات التاجية ينتمى لنفس عائلة الفيروسين المذكورين وهى العائلة التاجية هى التى دعتتا إلى إجراء هذا البحث. ومن أجل ذلك نم تصميم باديء (Primer) من المنطقة الجينية المسئولة عن تكوين البروتين المكون للزوائد التاجية لكل من الفيروس التاجى فى الأبقار وآخر من نفس المنطقة الجينية أيضا من فيروس الإلتهاب الثعبى المعدى للاجاج وبعد ذلك تم استعمال هذين البادئين فى اختبار تفاعل البلمرة المنسلسل (RT-PCR) على الحامض النووى لعدد من فيروسات الرومى التاجية والتى حصلنا عليها من قطعان رومى مصابة وأيضـا على السلالة المرجعية للفيروس. وكانت النتيجة أنه لم يتككن الباديء المحضر من الفيروس التاجى للأبقار من إكثار المنطقة المستهدفة

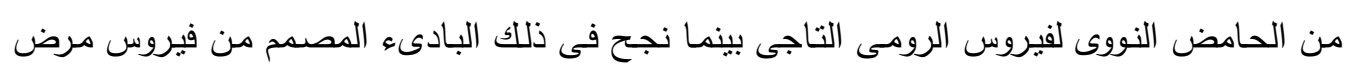
الإلتهاب الثـعبى المعدى للـاجاج. وهذه النتائج تعنى أن فيروس الرومسى التاجى أقرب مـن الناحية

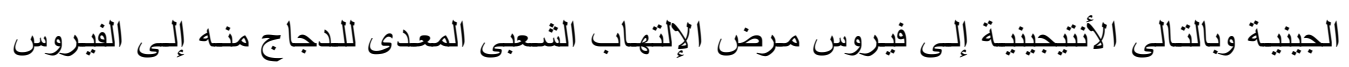
التاجى للأبقار وعليه يجب أن يصنف مع فيروس الإلتهاب الثعبى المعدى للاجاج فى المجموعة الثالثة

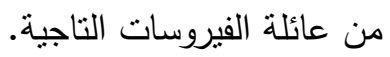




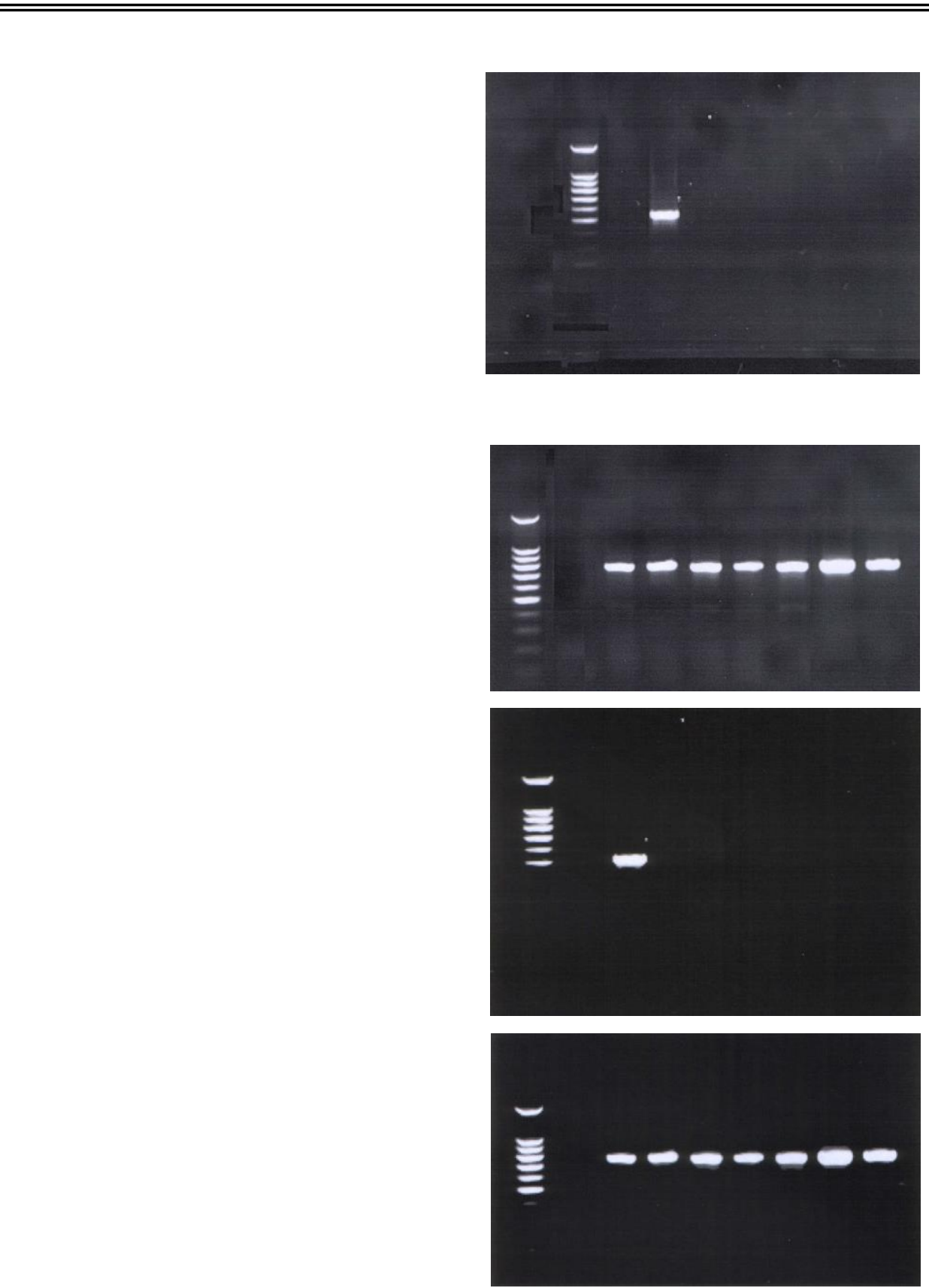

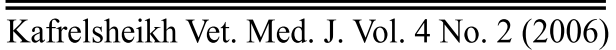

